\author{
Ана Блажева, (Северна Македонија) \\ Институт за општествени и хуманистички науки - Скопје \\ е-пошта: ana.gjorik@gmail.com
}

\title{
АФЕКТИВНИ ПОЛИТИКИ НА „АВТОНОМНАТА ЗОНА“: ОД МЕЛАНХОЛИЈА ДО ЗАЈАКНАТА ПОЛИТИЧКА АКЦИЈА
}

Апстракт: Текстот го истражува политичкиот потенцијал на меланхолијата како дел од афективните политики на „Автономната зона“, активност имплементирана од студентското движење „Студентски пленум“ во 2015 година во Македонија. Главниот фокус се однесува на афективниот потенцијал на „Автономната зона“ како времена, отелотворена и дејствена политичка пракса. На почетокот, во фокусот се психоаналитичкиот концепт за меланхолијата и нејзиниот социјален аспект. Социјалниот аспект на афективноста на меланхолијата е прикажан како маргинализирана позиција. Примерот што се користи во текстот се однесува на меланхоличната и маргинализираната позиција на студентите во македонското општество пред појавата на студентското движење. Следува теориската рамка, која поаѓа од современите интердисциплинарни пристапи кон отелотворено и дејствено ${ }^{1}$ социјално учество во споделениот свет. Овој пристап е феноменолошка перспектива кон социјалните акции што вклучуваат концепти како интерсубјективност, интертелесност и интерафективност. Овој пристап потоа се користи како основа за анализа на афективните политики инспирирани од Силвија Федеричи и нејзиното тврдење дека репродуктивната работа и сфера можат да бидат потенцијал за политичка имагинација и антикапиталистичка социјална трансформација.

Истражувањето и анализата се имплементирани врз специфичен дел на студентското движење „Студентски пленум“, отелотворено и дејствено воспоставено преку окупацијата на Универзитетот наречена „Автономна зона“ во 2015 година во Македонија. „Автономната зона“ траеше две недели во текот на кои студентите го организираа животот и просторот на Филозофскиот и Филолошкиот факултет на универзитетскиот кампус на „Св. Кирил и Методиј“ во Скопје. Анализата ги следи отелотворените, дејствените и интеркорпорални афективни искуства, доживувањето на просторот, интимноста, солидарноста и одговорноста како главни аспекти на афективните политики што беа употребени како политички алатки и како личен капацитет за трансформација. Анализата покажува дека афективните искуства на

1 Enacted-во случајот е преведено ‘дејствено' - неговото значење се поврзува со современите теории за емоциите каде што тие се разгледувани во постојана спрега со когницијата и во постојана реципрочна интеракција со околината. Дејствено тука означува динамична интеракција на организмот со околината, односно соучество во обликувањето на стварноста и светот. 
студентите за време на окупацијата биле најважниот аспект на трансформацијата на меланхоличното искуство и маргинализираната социјална позиција.

Клучни зборови: афективни политики, меланхолија, маргинализирани, интерсубјективност.

\section{Меланхолија на маргинализираните}

Психоаналитичките дискурси за меланхолијата ја објаснуваат несвесната динамика што го создава и го одржува меланхоличното искуство. Во овој дел од текстот дискутирам за психоаналитичките теории за меланхолијата на Фројд, Клајн и Кристева, а потоа ги користам концептите за расната и културната политика на емоции за да ја објаснам социјалната димензија на меланхолијата и нејзината динамика во социјалното поле.

Според Фројд, меланхолијата е патолошки процес на тагување, кој се разликува од непатолошкото тагување. Тагуваме по загубениот сакан објект. Тоа може да биде личност, идеја или сл. Во тагувањето, енергијата што била инвестирана во саканиот објект полека се повлекува од објектот и се пренасочува кон друг објект. Во меланхолијата, енергијата од катексата ${ }^{2}$ не се пренасочува кон друг објект, түку станува идентификувана со самото его. Односно „во процесот на тагување светот станува празен, додека во меланхолијата тоа се случува со егото“ (Freud 1917: 246). Идентификацијата на егото со загубата го овозможува пројавувањето на феноменологијата на меланхолијата (Freud 1917).

Јулија Кристева дава увид во меланхоличната позиција што ги заробува потенцијалите за надминување на отсуството на другиот, и така настанува затворањето во сопствениот меур (Kristeva 1989). Според Кристева, преку процесите на идентификација и интроекција, неповратна празнина се создава на местото на изгубениот објект. Ваквата прецизна интерпретација на психодинамските процеси на загубата и нејзиното влијание врз селфот не остава многу простор за интервенција или излез од изолацијата што е ефект од меланхоличната позиција.

Сметам дека студијата на Мелани Клајн за раниот развој на децата отвора можности за интервенција и излез. Нејзиниот пристап дава увид во комплексноста и меѓусебната поврзаност на психодинамските процеси. Клајн истакнува дека можностите за надминување на депресивните состојби се обезбедени преку создавање на репрезентации во внатрешниот свет во кој децата рефлектираат и ги трансформираат динамиките што се одвиваат во средината (Klein 1935). Според нејзиниот пристап, ништо не треба да се гледа надвор од комплексните релации и различните искуства што се резултат на постојана кокреација на детето со околината.

2 Во психоанализата катекса означува процес на инвестирање на ментална или емоционална енергија во личност, објект или идеја. 
Затоа моето читање на Клајн во таа смисла е во линија на интерсубјективните и дејствените пристапи кон емоционалноста.

Клајн, како и Фројд, ја опишува меланхолијата како загуба на објект или слична ситуација во која истото значење води кон повнатрешнување на загубениот објект во егото. Доколку интроекцијата не успее, тогаш наредниот образец на идентификација што се создава е „загуба на саканиот објект“. Релацијата со мајката и другите што се грижат за детето овозможува интернализација на овие искуства (Klein 1935). Пријатните искуства што ги зајакнуваат чувствата на љубов и доверба го намалуваат стравот, помагаат детето да ја надмине депресивната состојба и чувството на загуба (тагување). Децата ја користат надворешната реалност за да ја проверат внатрешната. Кога децата се чувствуваат сакани, што се искусува преку задоволство и удобност во врската со другите луѓе, тогаш овие искуства ги зајакнуваат нивните верувања во сопствената добрина и во добрината на другите и ја јакнат нивната верба. Тоа го намалува стравот и нивната внатрешна дезинтеграција и деструкција (Klein 1935).

Клајнобјаснувадекапостои комплекснапсихолошкадинамикашто овозможува перспектива и дава можност за надминување на меланхоличната позиција. Важно е да се забележи дека можностите за надминување и трансформација произлегуваат од искуствата на децата со возрасните, односно зависат од различниот квалитет на релациите. Затоа сметам дека трансформацијата на меланхоличното искуство е можна низ релациите што ги креираме во социјалното поле, а не како индивидуален и изолиран подвиг и резултат исклучиво на внатрешната динамика и потенцијали. Понатаму во текстот ќе биде разгледуван овој потенцијал за надминување на меланхоличната позиција.

Ен Ченг ја користи психоанализата за да ја разбере американската расистичка култура преку концептот „расна меланхолија“. Таа ја објаснува американската расистичка култура преку динамиката на отфрлање и интернализација на „другиот“ (Cheng 2000). Ченг објаснува како расната меланхолија може да се користи како концепт што помага во разбирањето на тагувањето и загубата не само како симптом туку и како динамичен процес со трансформативен потенцијал за политичка имагинација. Меланхолијата на маргинализираните овозможува теориска рамка за анализа на конститутивната улога на тагувањето во процесот на субјективизација. Јас ќе покажам дека трансформацијата на тагувањето и излезот од повредата можат да отворат политички потенцијал за маргинализираните субјекти и колективи.

Сара Ахмед прави анализа на културната политика на емоциите објаснувајќи ја феноменологијата на емоционалното искуство како дел од процесот на социјална промена. Таа покажува дека разбирањето на емоциите не е внатрешен психолошки процес, туку комплексен процес што секогаш веќе вклучува социјален аспект преку емоциите како културна практика. Во феноменологијата емоциите се поврзуваат со интенционалноста - секогаш се насочени „кон нешто“. За Сара Ахмед ова значи дека тие се поврзани со одредени ставови за светот и со начинот на кој го разбираме. Емоциите се појавуваат во релации што се обликувани од претходните истории на контактот со различни социјални и културни практики (Ahmed 2004). Таа смета дека емоциите циркулираат помеѓу објектите, површините и телата што се обликүвани од нив. Во овој текст го користам нејзиниот пристап за социјалноста на емоциите како отелотворени и вградени во контекстот. Таа ја користи својата анализа на болката да 
објасни дека, иако во болка, покрај субјективното искуство што не може да се сподели, интерсубјективниот аспект на болката ја обликува релацијата. Интерсубјективниот аспект не се однесува на чувствување на болката на другиот, туку преку присуството за/со другиот нашата релација е обликувана преку чувството што е присутно. Тоа значи дека емоциите никогаш не остануваат затворени во телото, туку секогаш веќе се дел од релациите што ги креираме со другите и со светот.

Новите интердисциплинарни пристапи кон емоционалноста во смисла на нивната отелотвореност и дејственост укажуваат дека „живееме во споделен свет разбран во смисла на учество и пошироки процеси на колективно креирање на значења што се манифестираат во динамични форми на интеркорпоралност, колективна телесна меморија, артефакти и сл. (Durt, Fuchs, Tewes 2017: 1). Овие пристапи предлагаат истражување на димензиите на емпатија, интерафективност, на идентификациите на себе со другите и херменевтско разбирање на мислите на другите (Durt, Fuchs, Tewes 2017: 1). Авторите го опишуваат споделениот свет како „изграден од интерсубјективно разбирање што ги открива нештата што имаат споделено значење за припадниците на одредена култура“ (Durt, Fuchs, Tewes 2017: 2).

Овој пристап е централен во анализата на отелотворените и дејствените искуства на студентите за време на окупацијата на Универзитетот наречена „Автономна зона“. Целта на овој текст е да се развие разбирање за тоа како споделениот простор и политичка визија се поврзани со интерсубјективните и интерафективните аспекти на искуствата на студентите и како овие искуства ги создаваат афективните политики што го трансформираат меланхоличното искуство и маргинализираната позиција на студентите кон зајакната политичка акција. Ова ќе биде придружниот аргумент во тврдењето дека меланхолијата има трансформативен потенцијал за зајакната политичка акција.

Теориската рамка за афективните политики како важен аспект на политичката имагинација што ја презентирам е инспирирана од работата на Силвија Федеричи, марксистичка феминистичка теоретичарка и активистка. Нејзината анализа покажа дека репродуктивната работа (работата што жените најчесто ја работат во домот и што ја овозможува репродукцијата и одржливоста на животот - преку грижа за исхраната, здравјето и сл. на децата, мажите и старите) била една од основите за одржување на капитализмот. Затоа таа смета дека репродуктивната сфера и работа треба да бидат основа за политичката имагинација и социјална промена. Моето мислење е дека афективниот аспект на репродуктивната работа е еден од суштинските аспекти што можат да се користат како концепт за политичка имагинација и социјална трансформација.

Во овој текст користам податоци од етнографското истражување спроведено во 2015 година за студентското движење во Македонија. Истражувањето беше спроведено за потребите на мојата докторска теза „Меланхолија и политика: Меланхолија на маргинализираните субјекти и заедници во Република Македонија“. Истражувачките методи што се користени во истражувањето се: деск-истражување за студентското движење „Студентски пленум“, набљудувања за време на „Автономната зона“ и 20 длабински интервјуа со десет студенти, учесници во „Студентскиот пленум“. Во овој текст користам податоци од деск-истражувањето, од теренските 
и рефлексивните белешки од набљудувањата и транскрипти од интервјуата со студентите.

Основното прашање на коешто ќе се осврнам во текстот се однесува на тоа како афективните политики на „Автономната зона“ овозможија трансформација на меланхоличната и маргинализираната позиција во зајакната политичка акција. Ḱe дадам кус опис на маргинализираната позиција на студентите пред појавата на движењето, а потоа кус опис и временската рамка на активностите што ѝ претходеа на окупацијата како важна заднина за овозможување на афективните политики на „Автономната зона“.

\section{Маргинализираната позиција на студентите}

Во овој дел од текстот се содржани контекстуални информции за позицијата на студентите во однос на нивниот социјален статус и студентско организирање. Деск-истражувањето покажа дека има малку податоци и истражувања за статусот на студентите и студентското организирање. Постојните информации и податоци нудат увид во предизвиците за студентското организирање и во општиот социјален статус на студентите.

Според документацијата на Универзитетот „Св. Кирил и Методиј“ (УКИМ):

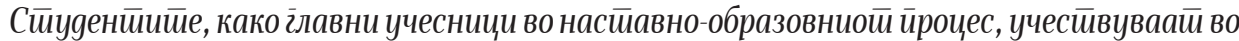

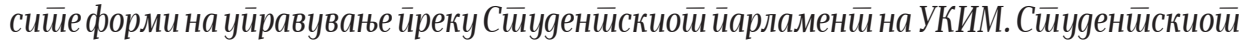

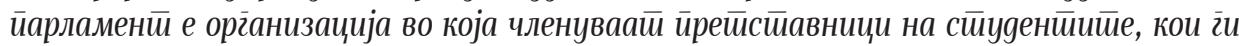

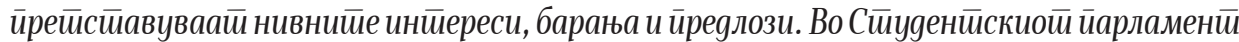

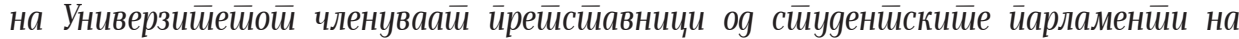

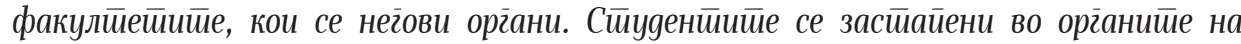

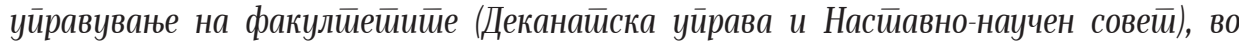

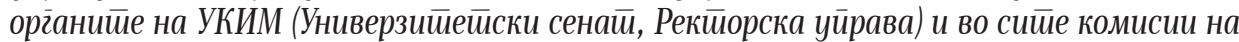

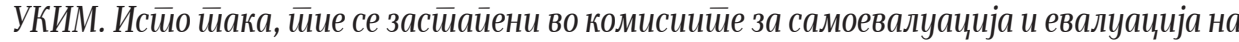

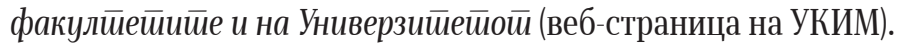

Со тоа единствено Студентскиот парламент и неговите претставници имаат право да бидат вклучени во процесите на носење одлуки. Меѓутоа, искуствата и податоците од истражувањата покажуваат дека Студентскиот парламент не ги одразува и не ги застапува потребите, барањата и ставовите на студентите (Попоска 2010). Покрај тоа, студентите се соочуваат со цензура на слободната мисла преку цензура на ораторските вечери организирани на Правниот факултет, затворање на студентското радио, непостоење на студентски весник или списание итн. (Попоска 2010).

Република Македонија нема богато искуство на независно студентско организирање и студентски движења. Првото современо независно студентско организирање започна во 2009 година со формирањето на Независното студентско движење - СЛОБОДЕН ИНДЕКС. Студентите од Слободен индекс се повикуваат 
на наследството на студентските движења од 1968 година и, според принципите на директна демократија, застапуваат бесплатно образование, студентско самоорганизирање, автономија на универзитетите и слободен, еманципаторен образовен систем³. Со слоганот „Да бидеме реални, да го бараме невозможното“ се обидоа да предизвикаат артикулирање на незадоволството на студентите. Овој слоган го користеше и „Студентскиот пленум“ во најавата на „Автономната зона“ и на протестите, и тој на некој начин го означува континуитетот на мислата и идејата за студентското организирање од 1968 до денес.

Маргинализацијатанастудентитесеогледаи востудентскиотстандард:лошите услови за студирање, немањето пристап до современа научна литература, лошите услови во студентските домови, малите стипендии и кредити, нефункционирањето на студентскиот правобранител, непочитувањето на етичките кодекси итн.

Маргиналниот статус на студентите и незадоволството од студентскиот стандард можат да се доловат и преку неколку статии за животот на студентите во последната декада.

Студентите во студентските домови се соочуваат со расипани лифтови, темни ходници, супстандардни услови за одржување хигиена, без топла вода, соби со мувлосани зидови, еднолична и количински недоволна храна. Еве еден извадок од исказ на студент што зборува за условите во студентските домови и за студентскиот стандард ${ }^{4}:$

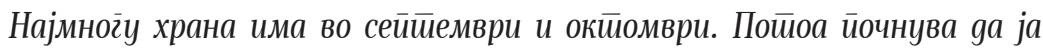
снемува. Оg месо, гоодинава имаше само сйек. Во мензайа имаше залейен лисй на кој йишуваше gека секој може gа земе само йо 200 ір. сииек. Се

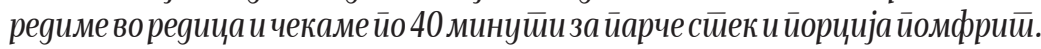

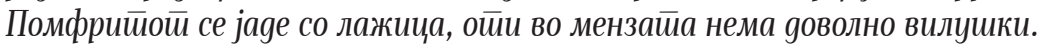

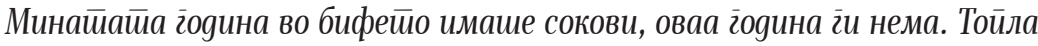

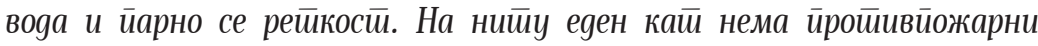

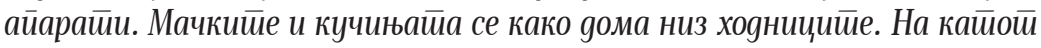

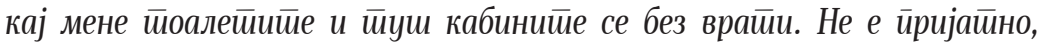
но мора gа ги корисииме, ойи gругоо нема. Во секој блок има йо gва лифйа, еgен сиїурно знаеш gека не рабойи. Низ ходницииее е хорор,

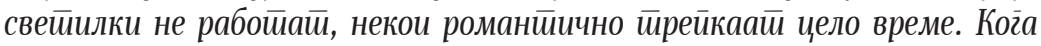

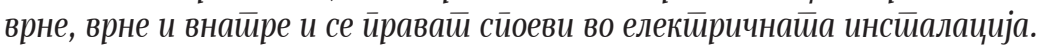

3 Статут, Независно студентско движење - СЛОБОДЕН ИНДЕКС, http://slobodenindeks. blogspot.mk/p/blog-page_160.html пристапено на: 14.10.2018.

4 Студентите од „Гоце Делчев“ тежат половина милион евра годишно - Министерството не знае како се трошат овие пари (30 септември 2014 година) - статија поддржана од проект за истражувачко новинарство, објавена на порталот „Актуелно 24“, http://aktuelno24.mk/fotostudentite-od-gotse-delchev-tezhat-polovina-milion-evra-godishno-ministerstvoto-ne-znae-kakose-troshat-ovie-pari 
Сликите на ужасот сведочат дека надлежните ја понижуваат студентската младина. Студентите со своите искази го потврдуваат маргинализираниот општествен статус.

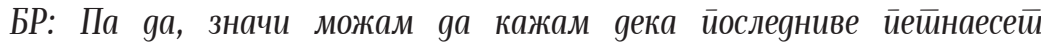

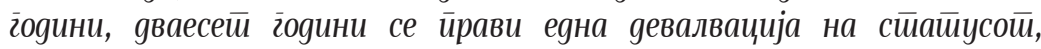

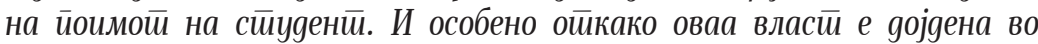

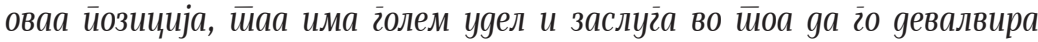

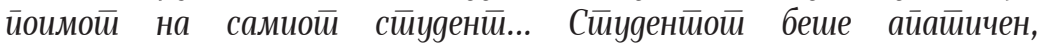

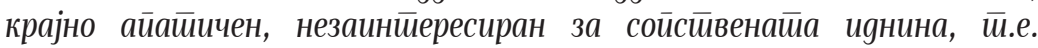
заиниеересиран за својайа иянина, меѓуйоа не во іраницииее на

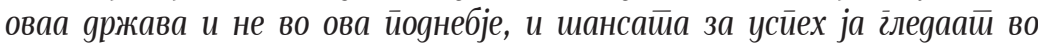

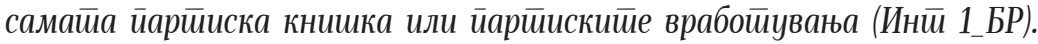

Меланхоличната позиција на студентите се огледа и во нивната апатија, збунетост и затвореност, соочени со неизвесноста, невработеноста и немањето можности за себереализација.

КМ: ...Имав сосема некои друг̄и йланови, gа најgам рабойа, gа сеgнам

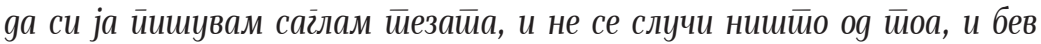

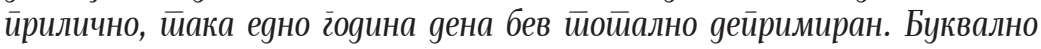

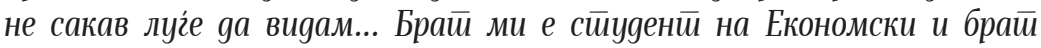

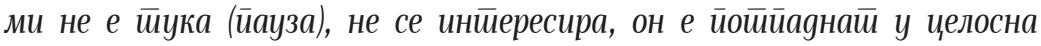

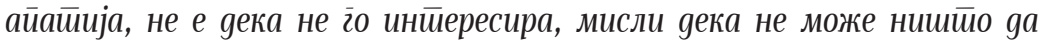
смени... Мног̄у е лесно gа се йаgне во айайија, йремног̈у е лесно, вие

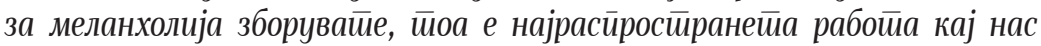

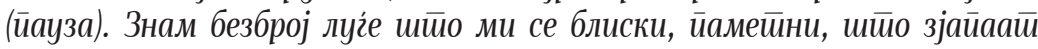

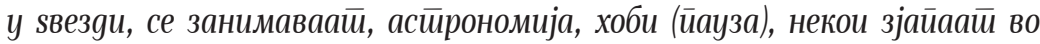

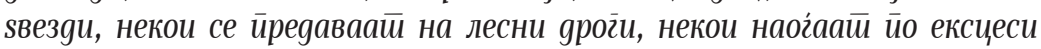

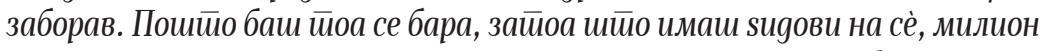
йрейреки. Секој gен гллеgаш колку си немоќен и йолека го йрифаќаш йоа.

Меланхоличната позиција е поддржана и со позицијата што студентите ја имаат за време на студиите, третманот во институцијата, од професорите. Нивните очекувања и потреби да бидат мотивирани и нивниот стремеж за високи постигнувања не наидуваат на услови што тоа го овозможүваат.

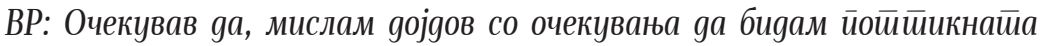

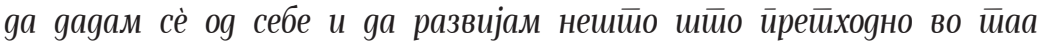

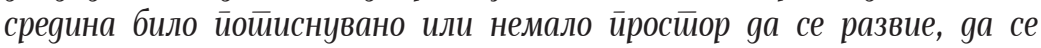

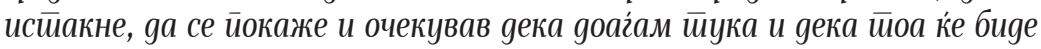
извлечено оg мене, ќе бияе йойиикнайо, ќе му биgе gаgено йросйор,

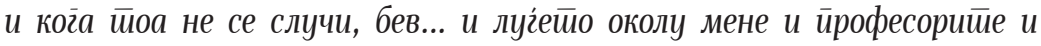




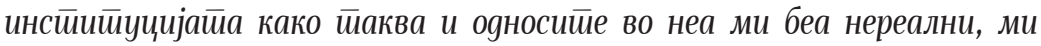
беа назаяни! Неочекувано конзервайивни! Тойално неочекувано.

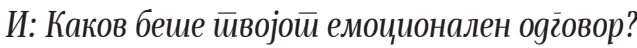

BP: Ме йовреgи! На некој начин... и... бев или йовлечена или аг̄ресивна,

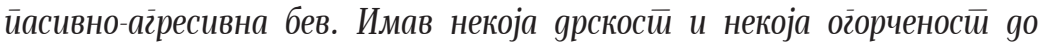
некој сиейен, и йаа се оgразуваше. Знаев gа развијам дискусија на која

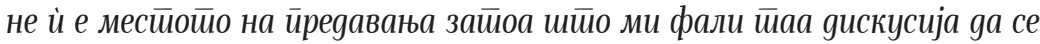

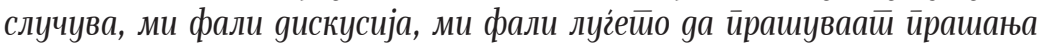

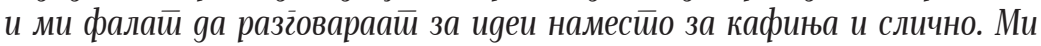

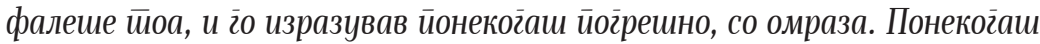

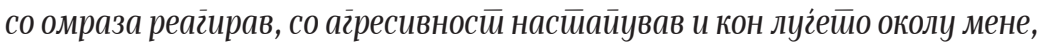

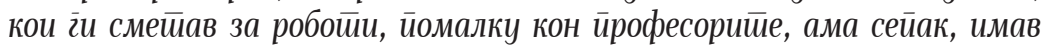

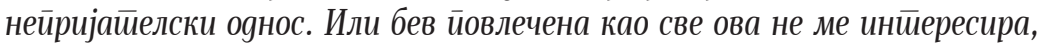

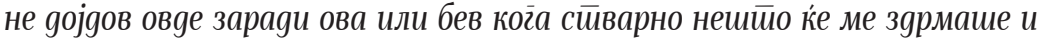

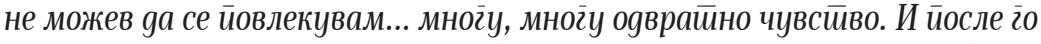

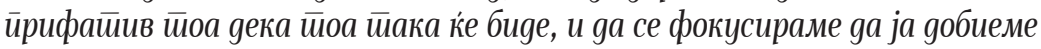
йаа gийлома... и ииочнав gа одам наоколу како робой некој айайичен...

Меланхоличните искуства зборуваат за разочараните очекувања, за неисполнетите лични потенцијали, интереси и потреби, кои се третирани како неважни и нерелевантни. Ова придонесува студентите да се чувствуваат незадоволно, депресивно и во подредена положба.

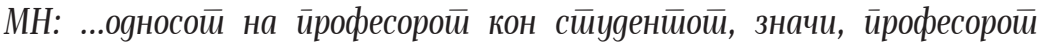

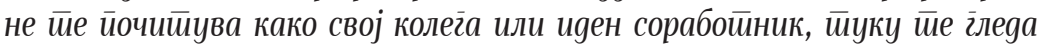

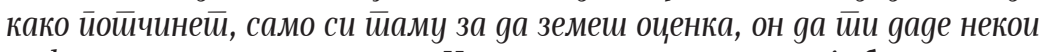

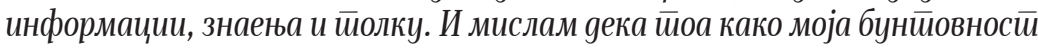

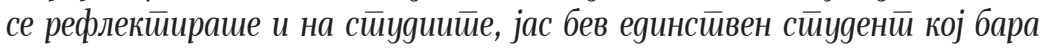

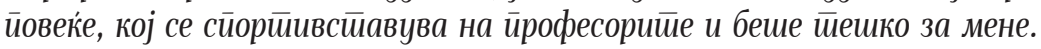

Преведено во псохоаналитички дискурс, маргинализираната позиција на студентите е резултат на загубата на нивното место и значење во општеството, на запоставувањето на нивниот потенцијал и на неоддавањето признавање и почит. Студентите тагуваат поради исклученоста, потчинувањето, губењето на самодовербата и себевреднувањето.

\section{Поставување на „Автономната зона“}

„Автономната зона“ беше формирана како дел од политичката стратегија на „Студентскиот пленум“, студентското движење формирано во 2014 година како реакција на најавата за нови измени на Законот за високото образование. Промените 
на Законот, за поголем дел од студентите и професорите, претставуваа закана за автономијата на Универзитетот преку наметнување на екстерна евалуација на знаењето и воведување систем на екстерно тестирање, подоцна наречено „државен испит“. Првиот студентски протест беше одржан на 17 ноември 2014 година и наиде на голема поддршка во јавноста. Вториот протестен марш беше одржан на 10 декември 2014 година, и на него маршираа повеќе од 10000 луѓе. Студентите поднесоа барање до Владата со аргументација против промените во Законот за високото образование.

Меѓутоа, Собранието ги усвои промените во Законот за високото образование, и тој влезе во сила. Студентите го најавија бојкотот на наставата и окупацијата на Универзитетот. Окүпацијата беше наречена „Автономна зона“ и беше закажана за 11 февруари 2015 година на Филозофскиот и Филолошкиот факултет на Универзитетот „Св. Кирил и Методиј“ во Скопје. „Автономната зона“ беше подготвена преку информирање на студентите од сите факултети и бојкотирање на наставата. Окупацијата беше политичка алатка што имаше неколку различни цели. Првата, да ја потврди автономијата на Универзитетот, потоа да направи притисок кон Владата да ги повлече измените на Законот. Покрај политичкиот и стратешкиот аспект, овој политички гест може да се гледа како процес што овозможи зајакнување на студентите и нивно репозиционирање во општеството. Тоа беше чин на заземање на политички простор и експериментирање со отелотворена и дејствена визија за слобода и демократија.

На првиот ден од „Автономната зона“ студентите го организираа животот во зградата на факултетите. Ги поставија правилата и патролите за безбедност, поставија катче за храна и пијалаци, простор за креативно изразување и ги организираа „спалните“ соби во предавалните. Отворија повик за донации за основните потреби - храна, хигиена, покривки и сл. Образовна и културна програма беше подготвувана за секој ден и објавувана на фејсбук-страницата на пленумот. Околу педесетина студенти ја поминуваа ноќта на факултет. Околу педесет до сто студенти беа постојано во холот како главно место за социјализација и одржување на настани. Неколку дена по успешната окупација и искуство на Филозофскиот и Филолошкиот факултет, окупацијата се прошири и на други факултети - Педагошкиот факултет, електротехничките факултети, Факултетот за архитектура, Факүлтетот за земјоделие и шумарство и Ликовната академија.

На четиринаесеттиот ден од „Автономната зона“, на 24 февруари 2015 година, се одржа вториот состанок на работната група со засегнатите страни - студентите, професорите, претставниците на Ректоратот и Министерството за образование и наука. На овој состанок сите вклучени страни се согласија дека ќе се изработува нов Закон за високото образование. Студентите и професорите го прифатија овој договор како победа и прославија со забава објавувајќи крај на „Автономната зона“ и окупацијата на Универзитетот. Два дена потоа „Автономната зона“ заврши.

\section{Феноменологија и афективни политики на „Автономната зона“}


Овој дел го опфаќа афективното искуство, организацијата на животот и живеаното искуство преку аспектите на интимност, интерсубјективност, дијалог, солидарност и одговорност. Афективните искуства на студентите за време на „Автономната зона“ овозможуваат преглед на трансформираната меланхолична позиција во зајакната и артикулирана политичка акција.

Афективната феноменологија покрива голем опсег на емотивни искуства и атмосфера. Ова вклучува чувства на задоволство, возбуда, љубов, восхит, емпатија, несигурност, страв, анксиозност, лутина и бес. Студентите зборуваа за постојаната возбуда што ја чувствувале и леснотијата да пристапат и да бидат со другите. Моќни политички афекти исто така го сочинуваат нивното живеано искуство. Тие го опишуваат своето доживување како триумфално, револуционерно и победничко. Често користеа зборови како енергија, магија и сл. за да ја опишат атмосферата во „Автономната зона“.

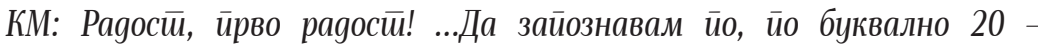
30 луѓе на gен, мене ми беше раgосй! Мене ми беше ӣоа убаво...

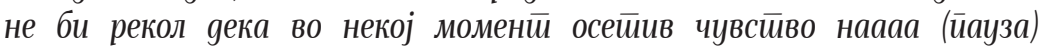

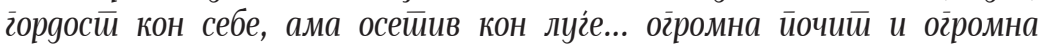

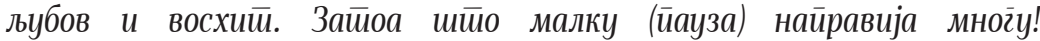

МН: Мислам цело време беше мног̈у како аgреналиной йокачен, и ког̈а

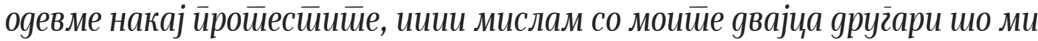

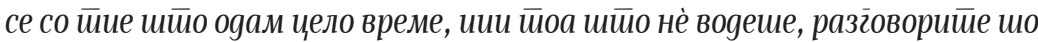
zи йраевме. Можеби на некој инфанииилен начин йака револуционерски

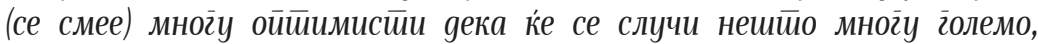

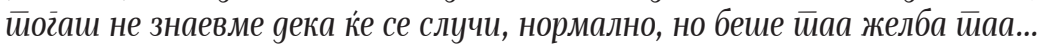

Овие афекти ја мапираат социјалната и политичката трансформација на меланхоличното искуство и на маргинализираната позиција на студентите. Тие ја овозможуваат интраафективната перспектива на трансформацијата. Имено, трансформацијата е споделено искуство, не единствено индивидуално доживеано. Моќта на трансформацијата може да се забележи исто така преку зголемениот интензитет на афектите. Психодинамски и контекстуални елементи може да го објаснат ваквиот интензитет. Првиот елемент е брзата трансформација што се случи за краток временски период. Од позиција на апатија и изолација до точка на егзалтирано задоволство и моќ. Ваква афективна трансформација може да го засили доживувањето на емоциите. Покрај тоа, јавноста реагираше со голема поддршка и внимание, а фактот дека студентите беа во фокусот на јавното внимание и поддршка исто така влијаеше врз афективниот интензитет. Исто така, новината на ситуацијата, интензивната размена, динамиката и опсегот на настани што се случуваа влијаеја емоционалното доживување да биде зголемено и нагласено. 
БР: Бооо, gа. Посйојано имаше адреналин, и йосйојано бев во еgна сийуација на еgна силна возбуgа! Имаше значи мног̄у возбуgа,

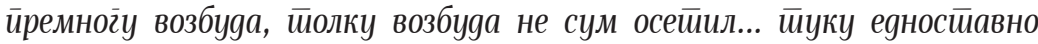

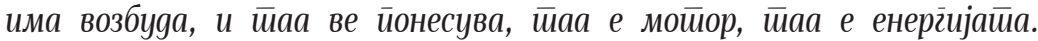

Ваквата афективна атмосфера ги исцртува рамките на афективната политика и е втемелена во специфичен материјален контекст. Имено, просторот исто така беше дел од трансформацијата. Затоа, важен аспект на „Автономната зона“ беше просторот што го заземаше. Тоа што претходно било административно, институционално место беше трансформирано во интензивен, споделен социјален, политички и интимен простор. Трансформацијата на просторот го рефлектира интерсубјективното искуство, при што зидовите стануваат место за артикулирање на политичките барања и политичката визија, воздухот е исполнет со музика што ги рефлектира афективните, социјалните и политичките перспективи. Студентите го доживуваат просторот поинаку бидејќи просториите за предавања служат како спални соби, додека просторот е исполент со нивната омилена музика и креативни работилници.

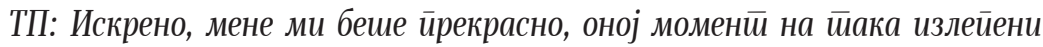

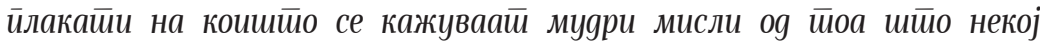

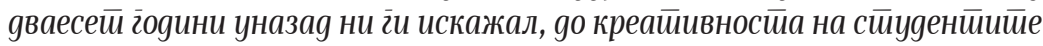

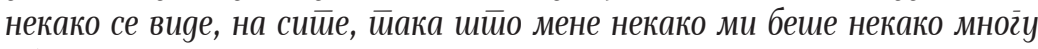

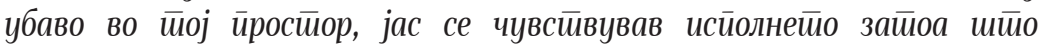

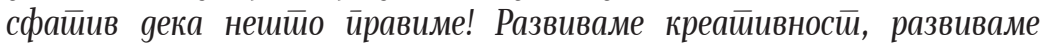
ум, развиваме осиирина, развиваме крийичка мисла, развиваме буквално наше кайче во кое секој оg нас има йо еgна, како се вели,

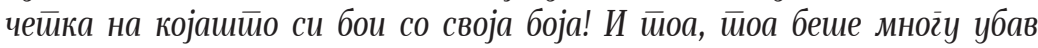

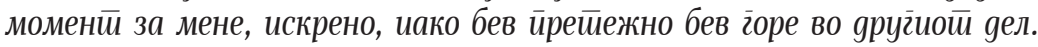

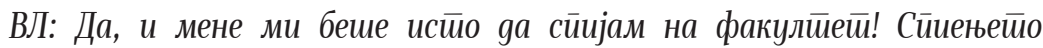
ми беше еgен оg најчуgнитее gелови во сейо йоа... Да, се йокриваш

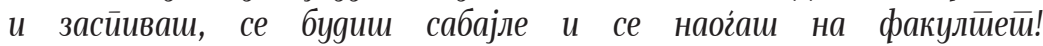

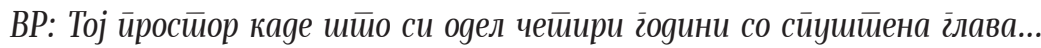

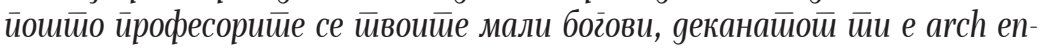

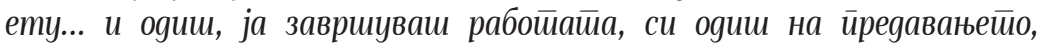

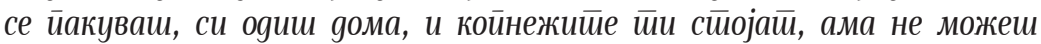

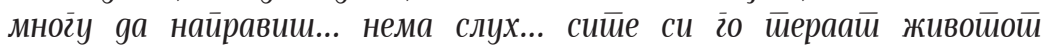

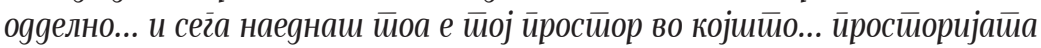

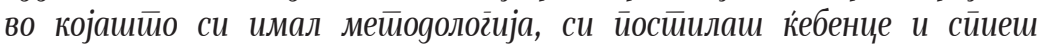

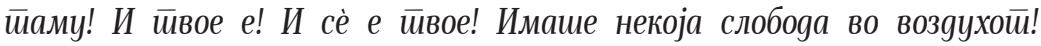

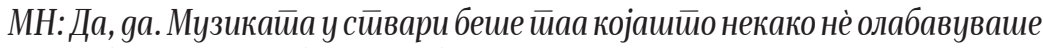
сииее, бияејќ сийе бевме слобоgни gа оgиме gа йушишиме музика која ја

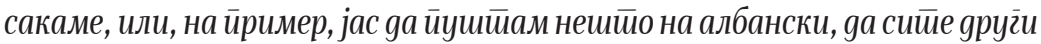




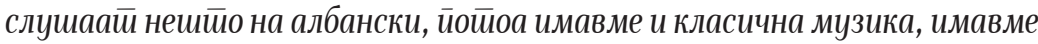
и мног̈у gругіи, имавме и фолклорна музика, имаше и мног̄у различни.

Организацијата и преуредувањето на просторот се во функција на актуелните потреби иполитички ставови и ја одразуваат новата отелотворена идејственапозиција на студентите. Студентите го трансформираа просторот, и нивното меланхолично искуство беше исто така дел од трансформацијата. Тие оваа трансформација ја објаснуваат како зајакнување.

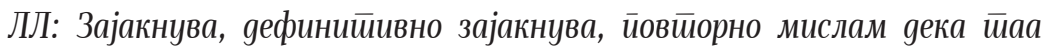
извесносй која е креирана оg сиие и која е... не знам, која означува еgна

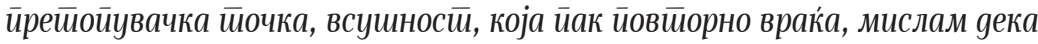

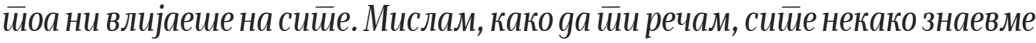
gека е океј. ...Да, ирремолчано беше gека сме... gека не ни е жал, gека не е

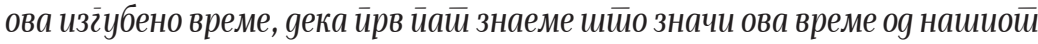

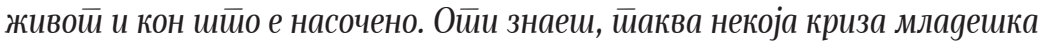

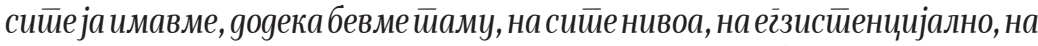

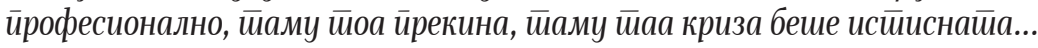

Новото и уникатно искуство во организирање на животот преку секојдневните активности како спиење, хигиена, исхрана и сл. сместени во академски контекст и политички ангажирани за автономијата на Универзитетот ја отелотвори новата визија за него. Визијата беше и физички и социјално и емоционално живеана за време на окупацијата. Затоа, окүпирањето на просторот, живеењето и работата во тој простор за студентите е значаен симболички израз, потфат и поддршка, значајна политичка одредница на која инсистираат (преговорите да се одвиваат на академска почва). Преку окупацијата и редефинирањето на просторот тие го изразија не само својот бунт туку извршија и политички притисок и воедно ја преобмислија визијата за Универзитетот и за своето учество во него.

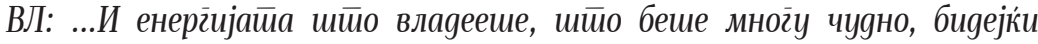

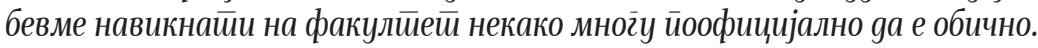
Иуеш на факулиеей, ияеш на йредавања, си излеїуваш, си ияеш gома.

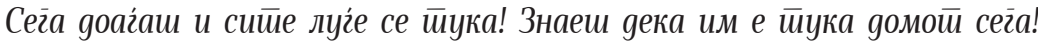
Дека нема gа си оgай никаgе (се смешка), дека никој нема gа си оgи никаgе, йука сийе ке бияеме, ова е нашиой дом. Чудно беше (се смешка).

Квалитативно поинакви односи се развиваат со професорите на начин што е поотворен и непосреден без административните граници, и во ваква релација како еднакви зборуваат за промените во академијата. Релациите меѓу студентите се најважниот дел на интерсубјективното искуство за време на окупацијата. Овој интерсубјективен аспект има трансформативна моќ за меланхоличното искуство и маргинализираната позиција. 
Релациите беа воспоставувани и развивани преку два паралелни процеси: организацијата на животот во „Автономната зона“ и политичката делиберација и дијалог како дел од пленумските сесии. Двата процеси беа еднакво значајни за формирањето на заедницата. Првиот процес ги покрива аспектите на поврзување преку социјализацијата, интимноста и припаѓањето, додека другите се однесуваат повеќе на идеолошките и политичките аспекти на релациите. Ќе се осврнам прво на организацијата на животот, а потоа и на политичките аспекти на делиберацијата и дијалогот.

Промената на начинот на социјализација е еден од аспектите на ова интерсубјективно искуство. Студентите споделуваа искуство дека, наместо да бидат постојано со мобилните телефони, можат да разговараат едни со други, да играат социјални игри без да бидат „онлајн“. Животот во оваа нова заедница што самите ја создаваа донесе нова светлина и поинакви афективни вредности за релациите со нивните врсници. Тие уживале во непосредниот контакт што го имале и го разменувале и во блискоста што им била овозможена.

ТП: ...ама йа имаше и мног̄у смеење, йака, на иример, некаgе околу

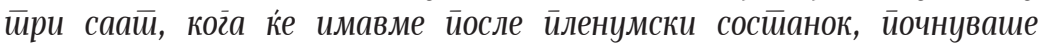

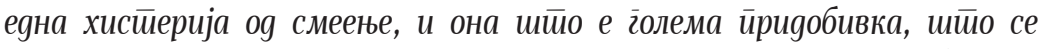

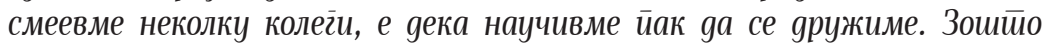

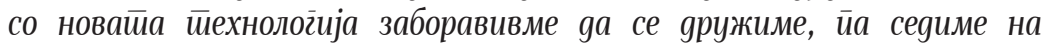

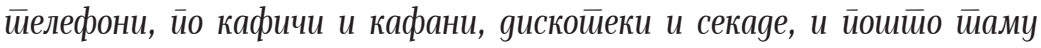

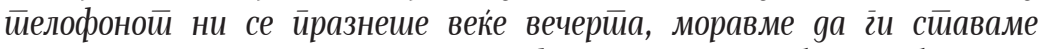

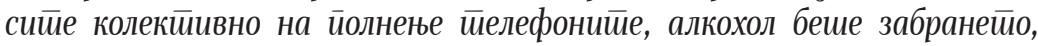
ааа ние учевме gа се gружиме и gа зборуваме, без gа имаме gејсивво на алкохол за gа се ойушишиме, без иеелефон за gа йровериме

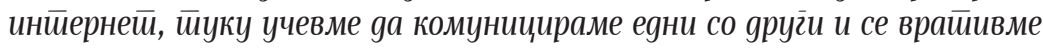

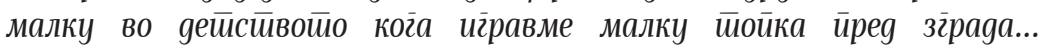

БГ: Искрено чуgно, не, не знам како gа гоо ойишам, йоа е инсииийуција

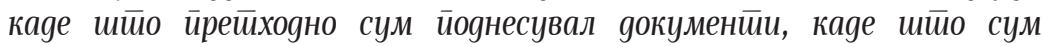

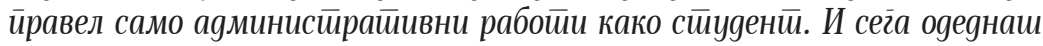
йрофесориіие сеgеа со нас, йиевме кафе, йушевме цийари заеgно, се

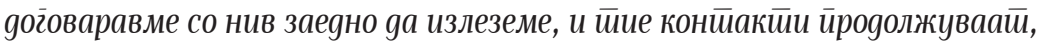

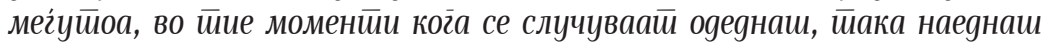

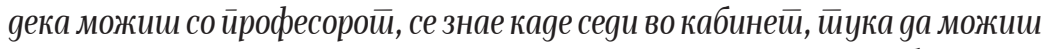
нейосреgно gа разговараш и gа gискуйираш за шо и gа е слобоgно... И

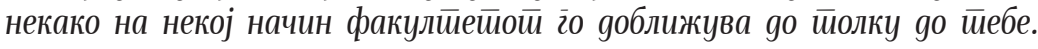

Самиот акт на создавање заедница во која членовите се вклүчени во репродуктивните аспекти на секојдневното живеење ја дава феминистичката димензија на политичкиот акт. На тој начин се потврдува феминистичката заложба дека „приватното е политичко“, и не само тоа, туку се истакнува важноста на ставот дека процесите од интимната, репродуктивната, „женската“ сфера се неизоставен дел од креирањето на заедницата и во политичка смисла. Политичкиот 
акт или функција на заедницата неопходно подразбира нејзино еманципирање (феминистичко, емоционално, идентитетско и економско). Во таа смисла, значајна компонента на „Автономната зона“ е неисклучивоста, инклузивноста и во однос на идентитетските прашања. Покрај тоа, „Автономната зона“, иако микрозаедница во однос на општествената, имаше влијание и врз еманципирање или предизвикување на економските процеси, особено за членовите на заедницата. Тоа беше јасно отсликано во начинот на кој беше организирано подмирувањето на основните потреби преку концептот на солидарна економија. Студентите ја препознаа моќта на репродуктивните и интерсубјективните процеси на нивното искуство и организираа предавање во рамките на „Автономната зона“ насловено „Женското лице на револуцијата“, кое се однесуваше на феминистичкиот аспект на создавањето заедница.

БР: Имаше еgна женсиивена морфолог̄ија! Значи воойшӣо гоо немаше

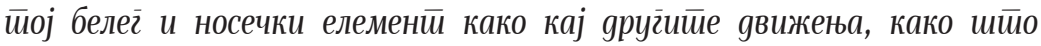
можеме gа го сойлеgаме, на иример. Имаше иниеересен, мислам gека

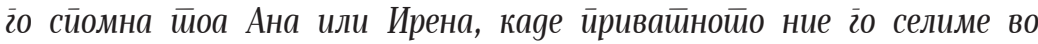

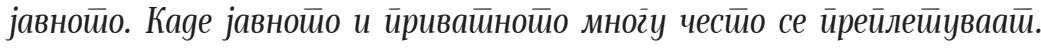

Заедно со репродуктивниот аспект, друга димензија на интерсубјективното искуство што го истражував со студентите беше интимноста. Студентите упатуваа на различни аспекти на интимноста што ги доживеале или ги промениле за време на окупацијата. Зборуваа за отелотворените доживувања на споделување на интимниот простор во новото окружување, како и за промените во интимните релации со другите. Студентите зборуваа во контекст на преговарање и превреднување на сопствените ставови кон сексуалноста, етничноста, идеологијата како дел од интимните трансформации што резултираа од искуствата за време на окупацијата.

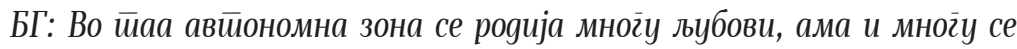
скараа, раскинаа, се роgија нови йривлекувања, се роgија нови сйавови шимо йи не си гेи имал баш йреку инииимни gоживувања. Мислам gека на

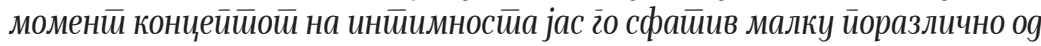
йорано, gел ја создаваш сонови луѓe, којае нова, која ейаралелна, ӣоширока

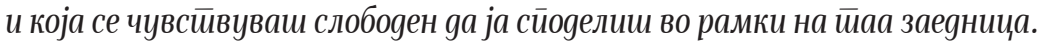

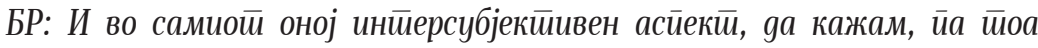

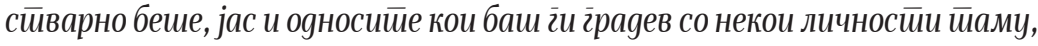

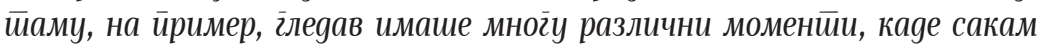
gа сум сам, ама а сум меѓу нив. Значи, имаше еgна иниеересна маг̈ија! Јас најчестио, ког̃а сакам gа сум сам, не сакам gа сум со луѓе, си одам gома и сакам gа не ми смейа никој, а ваму бев сам, бев йосйојано во gијалог̈ со самиой себеси, меѓуйоа бев ойкружен со луѓе! Тоа беше како еgна нова симболичка йараgиїма за мене. И сам и со gруг̄ииее! Тоа е она ког̈а и како индивияуа се gоживуваш себеси, но и како еgна бескрајна

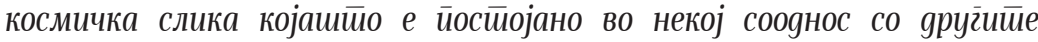

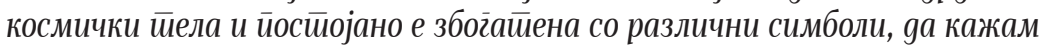


йака. Тоа сииварно беше иниеересна сийуација, йоа сииварно еgнаш во

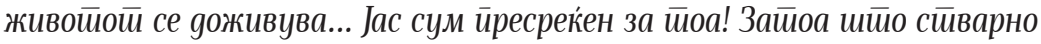

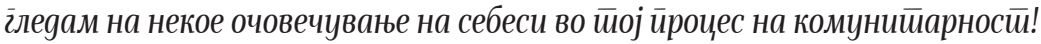

Одговорноста беше другиот аспект на дејственото искуство важно за студентите во нивниот секојдневен живот во „Автономната зона“. Тие ја презедоа одговорноста за себе, за животот, безбедноста и просторот што го освоија со окупацијата. Одговорноста беше издејствувана преку репродуктивната грижа за животот за време на окупацијата, но исто така и за преговарачкиот процес. Овие репродуктивни аспекти на организацијата за време на окупацијата се дејствениот аспект на искуството, директно поврзани со зајакнувањето на студентите и нивната посветеност на демократските вредности и најмногу со нивната позиција, улога и учество во Универзитетот. Нивното политичко зајакнување беше издејствувано преку посветување на процесот на преговори со Владата и Министерството.

СБ: Мора ние gа йокажеме gека искрено се грижиме за йакви рабойи

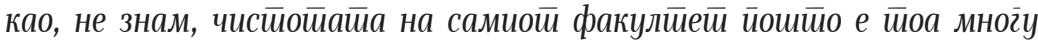

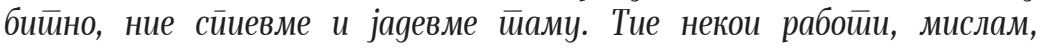

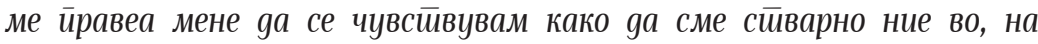
авйономна зона со којашйо ние уйравуваме (се смее), и йака и беше.

Студентите чувствуваат одредена гордост зашто успеале да покажат одговорност и конструктивност во целиот процес и, наместо револтот да биде искажан на деструктивен начин, тие го артикулираа создавајќи простор во кој можеа слободно да ја изразат својата критика кон образовниот систем, но истовремено да придонесат кон осмислување и практикување на нов пристап за тоа како би можело и како сакаат да се одвива образовниот процес.

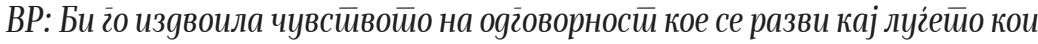

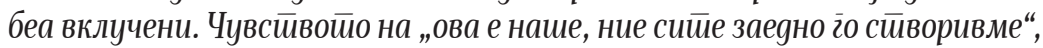

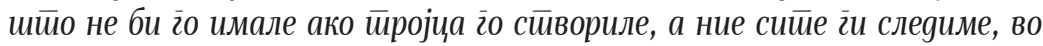
секој случај... „ова е наше и ние се ірижиме за негі“ и йреба gа си најgеме

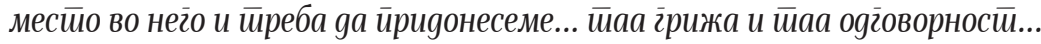

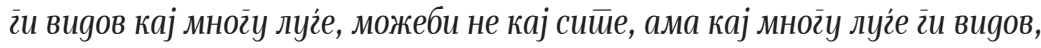

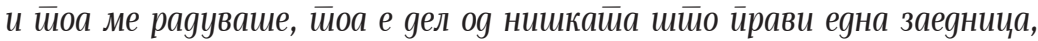

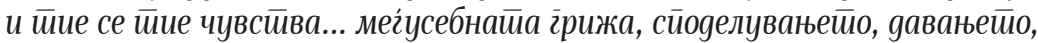

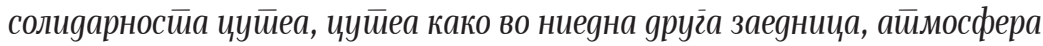

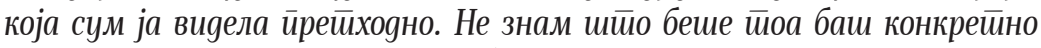

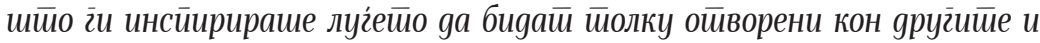

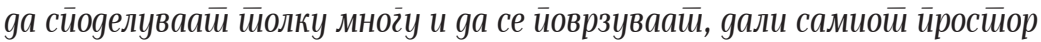

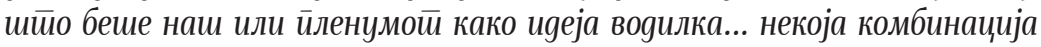
го найрави йоа и еgносйавно йосйоеше, и сѐ беше наше и сѐ беше заеgничко, и никој немаше... никој не ваgеше сиеереойийи, йреgрасуgи,

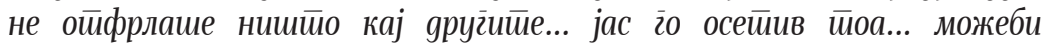

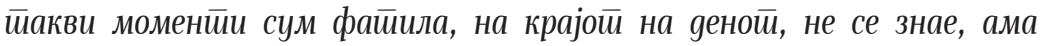




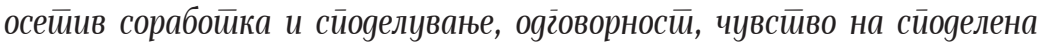

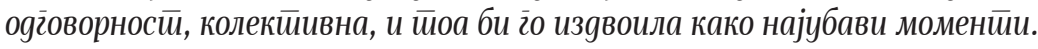

ЛЛ: Да, gа, во врска особено кон авйономнайа зона и дорржувањейо

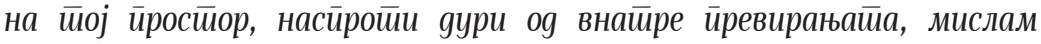
gека бевме мног̄y оgговорни. Без она... йоа, йоа созgавање на йаа

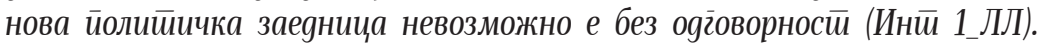

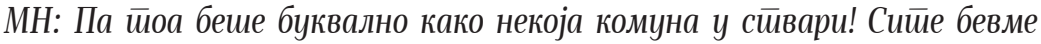

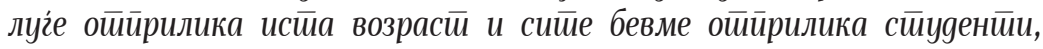

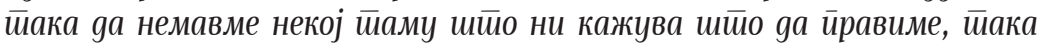

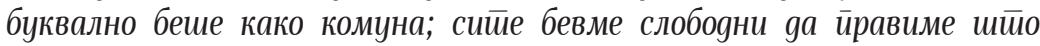
сакаме, не мораше некој gа не конирролира и gа ни кажува шишо не

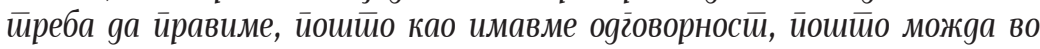

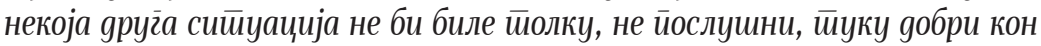

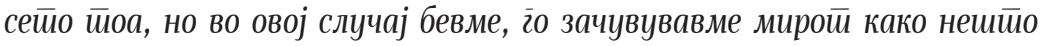
најсвейо, ако некој го иррекршува, веgнаш како gа не е еgен оg нас.

Чувството на заедништво не е само прашање на политичката димензија. За некои од студентите тоа претставува ново интимно искуство да се биде со другите, без принуда и ограничување, но значајно и кое креира чувство на исполнетост.

Солидарноста е уште еден аспект на интерсубјективната релација на грижа што се изразува преку конкретен акт на поддршка. Студентите ја сметаа солидарноста како еден од главните принципи на нивното движење и заедница, како и главен потпорен механизам за поддршка во нивното организирање и функционирање. Тие зборуваа за солидарноста во рамките на пленумот, како и за поддршката што ја добиваа од граѓаните преку донации, изразување поддршка, учество на протести, на социјалните мрежи и сл. Тоа ги прошири границите на нивната заедница посегајќи и солидаризирајки се со други социјални движења. Ги прошири социјалните граници преку инклузија на различностите и другоста.

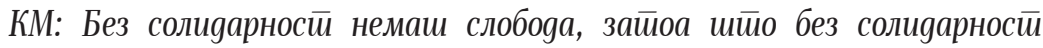

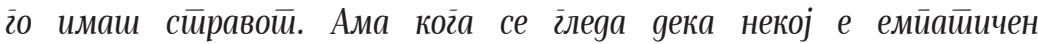
кон йебе, не можеш gа се йлашиш. А се гілеgа, се чувсиивува.

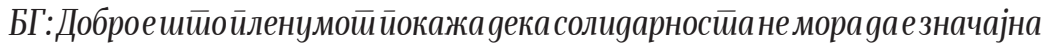

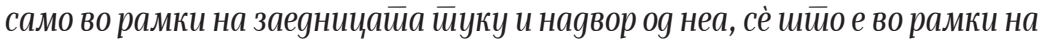

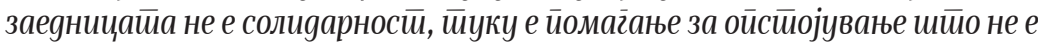

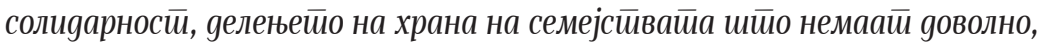
йокажа gека заеgницайа знае gа функционира и со gруг̄uие заеgници...

Еден од конкретните примери на солидарност се покажа преку примерот со јавното посрамување и говор на омраза на социјалните мрежи и во медиумите за еден од ЛГБТИ-студентите од движењето. „Студентскиот пленум“ како заедница и многу студенти лично јавно застанаа во одбрана. Овој акт на солидарност ја изразува инклузивноста на движењето како социјално движење што отворено ги поддржува 
ЛГБТИ-луѓето. Овие принципи не се само важни за кохезијата во студентското движење туку придонесуваат за демократизација и на јавниот дискурс. Дотолку повеќе ваквите примери на солидарност се значајни и за личното доживување на поединците и за нивното индивидуално зајакнување. Цитатот подолу го илустрира зајакнувачкиот момент на солидарноста за овој конкретен студент.

ВЛ: Тоа, мног̄у беше убаво, целайа енерӣија и сийе луѓе! Не знам, ког̄а се

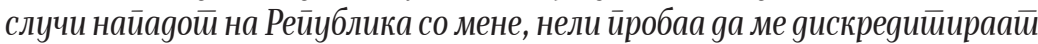

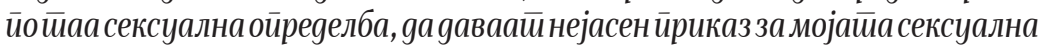

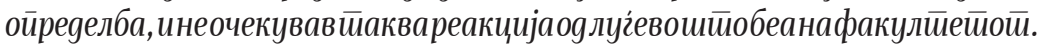

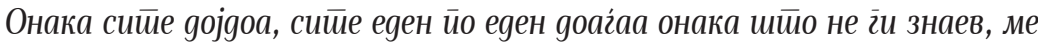

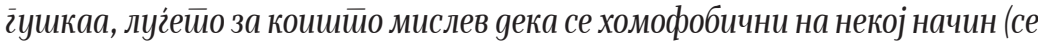
смее) ме гуушкаа, ми gаваа йоggршка, убави зборови, не ми се веруваше!

Овој пример исто така води кон друга поелаборирана димензија на солидарноста како нова граница на политичкото - подготвеноста да се преземе индивидуален ризик врз себе, врз сопственото тело како израз на основата за заедницата во политичка смисла.

ЛЛ: Ако морам инӣимно gа изложам и йоеgинечно gа изложам, мене ми е

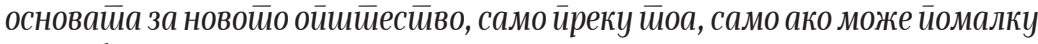
gа ја збориме, йовеќ gа ја йравиме. Шӣо значи gа ја йравиме? Тоа значи

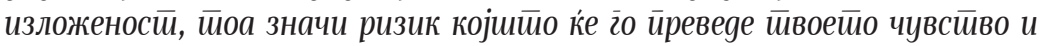

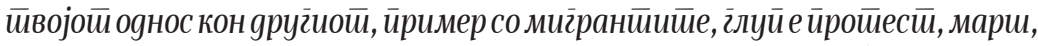
gругіо е конвој за йревоз, ӣоа е ирревземање ризик, ког̃а се иериближуваш gо

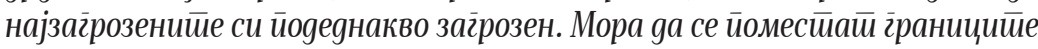

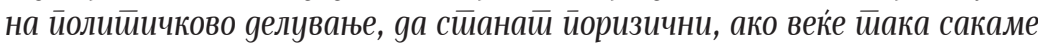

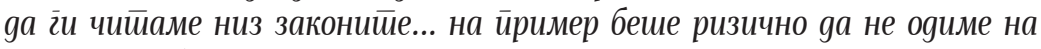
йрегоовори, беше ризично gа йрае, gа се йродолжи со окуйацијайа...

Ризикот што го презедоа студентите со окупацијата како политички чекор беше голем. Тие се изложија себеси на сите институционални регулативи што можеа да бидат искористени против нив и нивните постапки. На пример, некои од личните ризици со кои студентите се соочуваа беше губењето на испитните сесии, правото на потпис за присуство, губење на семестар и сл. Но тие исто така се изложија на безбедносен ризик што зависеше од одлуката и функционирањето на заштитните механизми за време на окупацијата.

Солидарноста разбрана како помош или поддршка или како преземање ризик или споделување одговорност потврдува дека е неразделен дел од креирањето на заедница заснована на принципите на прифаќање, одговорност и е фундаментална за афективните политики како политики на грижа.

Дијалогот е другиот аспект на интерсубјективното искуство на кој ќе се осврнам, поврзан со политичките процеси и дефинирањето на заедницата на „Автономната зона“. Овој аспект е најчесто поврзан со тековната делиберација во пленумските сесии, како и со неформалната комуникација меѓу студентите. Сакам да разгледам два аспекти на дијалогот, првиот како политичка алатка и другиот како интерсубјективен потенцијал за социјална и индивидуална трансформација. 
За студентите дијалогот во пленумот е неразделен од хоризонталната структура на движењето и принципот на еднаквост. Ова е главниот услов за овозможување на неопходната отвореност кон другиот изразена преку актот на слушање и земање предвид на түѓата позиција. Ова може да биде сумирано како емпатија, која студентите ја препознаваат како значаен квалитет и/или како услов за дијалог.

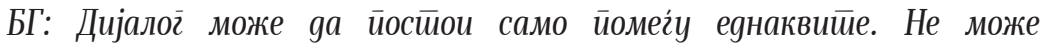

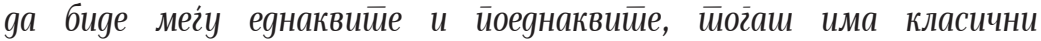

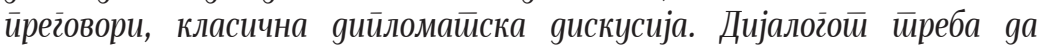

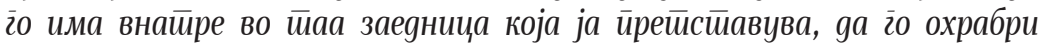

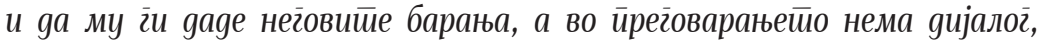

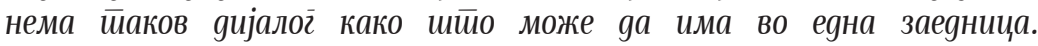

ВР: (йауза) Без емӣайија не може gа йосӣои gијалог̄. (йауза)

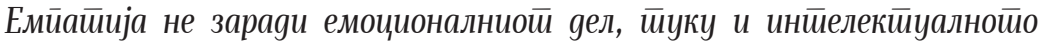

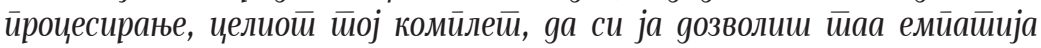

Студентите прават разлика помеѓу дијалог и дебата. Тие го разликуваат дијалогот преку капацитетот да се разбере другиот, да се емпатизира. Исто така го сфаќаат дијалогот како неопходен услов за демократските процеси. И дијалогот и дебатата се користат како политички алатки за избор на различни политички стратегии за остварување на различни политички цели. На пример: двете главни политички стратегии што студентите ги користеа беа институционалниот пристап (поднесување барања, поплаки, присуство на состаноци и преговори) и порадикален пристап (протести, окупација и сл.). За овие пристапи беше дебатирано и се одлучуваше на пленумските сесии, и тие беа линиите што ја зајакнуваа тактиката, но истовремено го правеа пленумското тело ранливо на идеолошките разлики и на влијанијата однадвор.

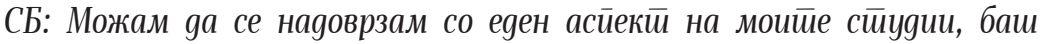

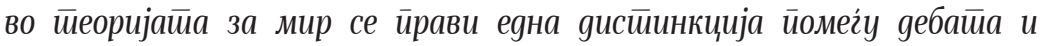

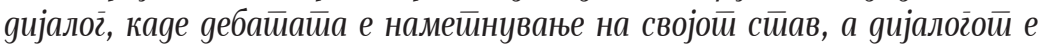

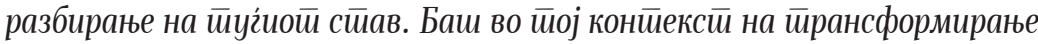

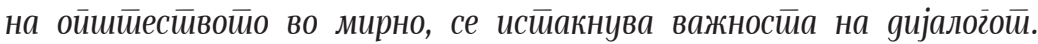
Јас лично го вреgнувам како значаен gел во разменайа на мислења

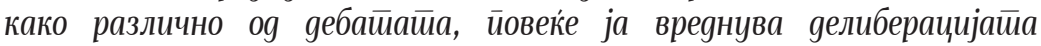

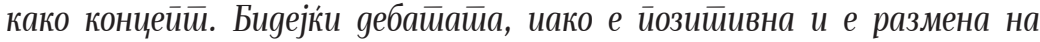

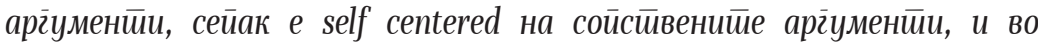

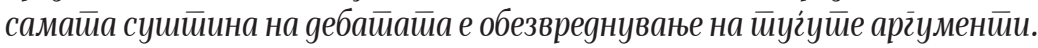

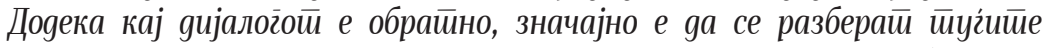

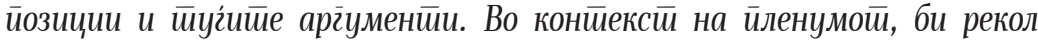

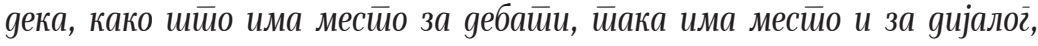




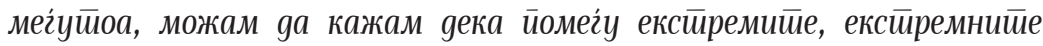
разлики, сейак има ӣовеќ месйо за дебайа, а йомалку gијалог.

И: Шӣо е неойхоgно gа има за gијалог̄?

ЛЛ: Тоа веројайно е врзано за хоризонӣалава, со лугево кои се вклучени...

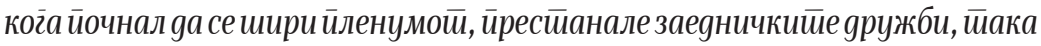

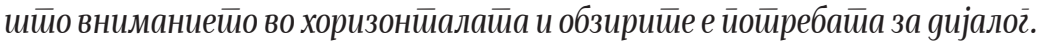

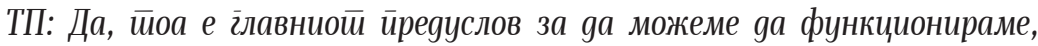

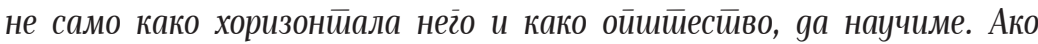

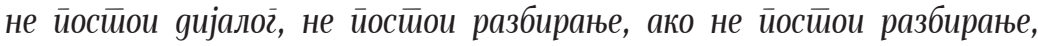

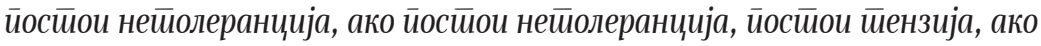

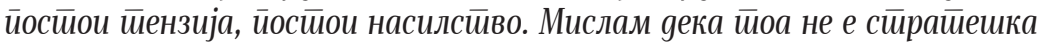

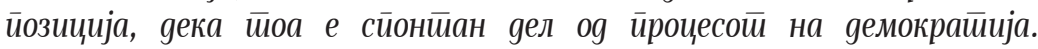

Еманципирачката улога на дијалогот може да се согледа преку можностите што произлегуваа од заедницата заснована на принципите на солидарност, еднаквост и разлики. Тој го носи потенцијалот за јакнење на одлуките и за редефинирање на позицијата на студентите во социјалното и политичкото поле, како и на личното зајакнување и развој. Така дијалогот служи како трансформативен потенцијал за меланхоличното искуство и маргинализираната позиција.

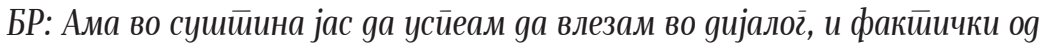

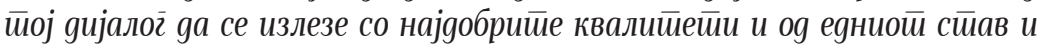

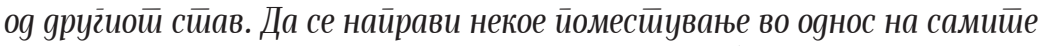

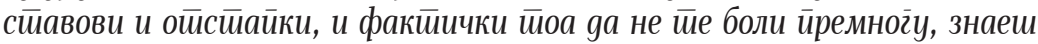
она... Ама иниеересно беше, и можам gа кажам, значи, можам gа кажам

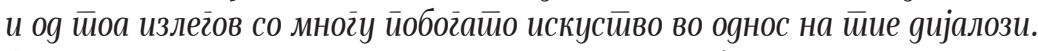

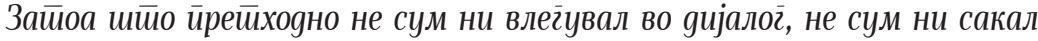

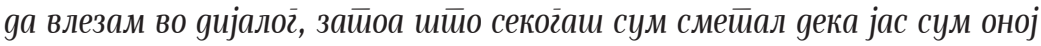

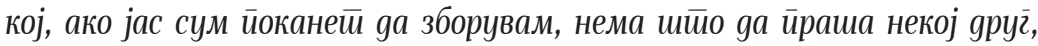

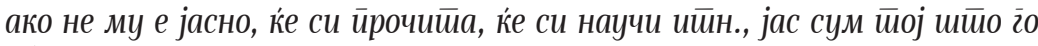

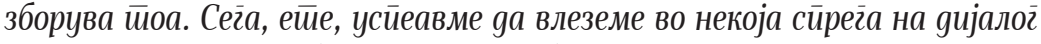
и на размена на симболи, макар симболично... можам gа кажам gека е

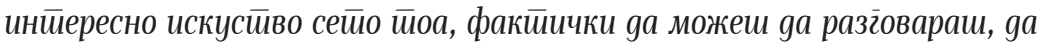

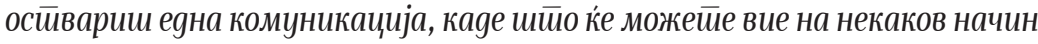

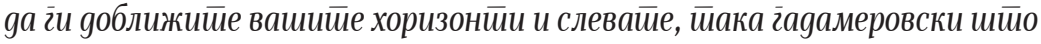

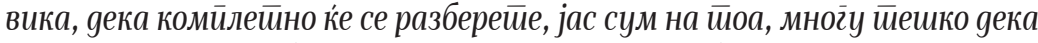
ќ можеме gа се разбереме. Меі́ушиоа, сейак оние зборови, оние кайеіории

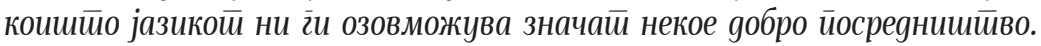




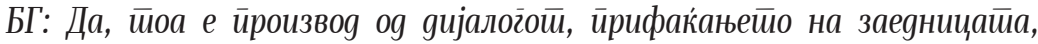

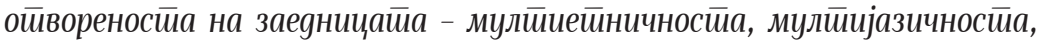

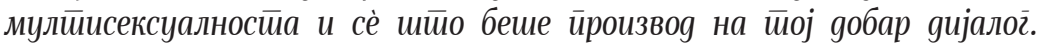

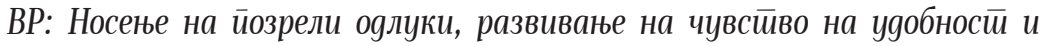

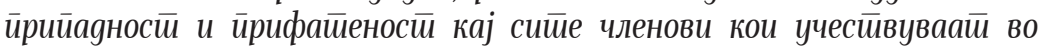

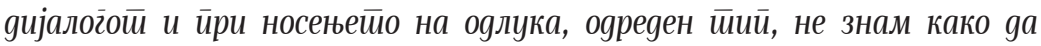

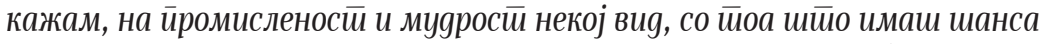

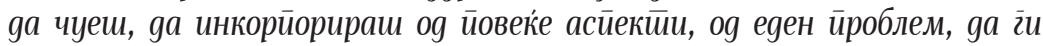
сублимираш; зацврснување на еgна заеgница, бияејки сѐ е на крајой еgна

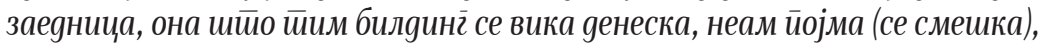

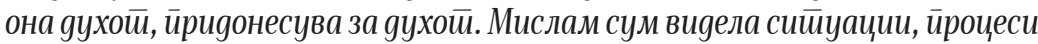

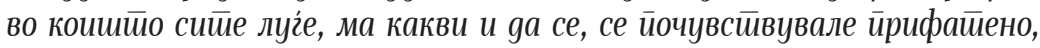
не йослушано нее... се йочувсиивувале йрифайено, е океј шйо се

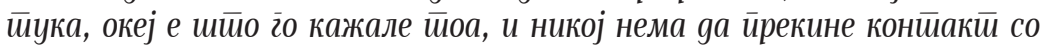

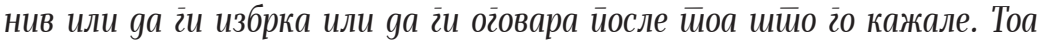

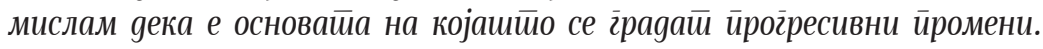

Најмоќниот аспект на интерсубјективното искуство на дијалог е токму тоа што се случува „помеѓу“, сферата што се кокреира го носи трансформативниот потенцијал. Овој потенцијал е можен единствено во полето на социјалното. Повторно дијалогот не е единствено индивидуално искуство, туку споделена, дејствена и отелотворена реалност и искуство.

\section{Заклучок}

Концептуализацијата на искуствата од „Автономната зона“ отвора можности за политичка имагинација. „Автономната зона“ има специфично значење што не е исцрпено со политичките барања на движењето, туку е процес на креирање нова заедница, која ги превреднува основните практики на функционирање на Универзитетот и општеството. Новата позиција на студентите во политичкото и социјалното поле беше освоена преку организирање на движењето и преку формирањето на заедницата на „Автономната зона“. Оваа трансформација беше делумно резултат на специфичните афективни политики на „Автономната зона“ отелотворени и пројавени преку афективните искуства, интимноста, дијалогот, одговорноста и солидарноста, при што студентите се чувствуваа зајакнати да преземат политичка акција. Актот на воспоставување на „Автономната зона“ прави прекин во постојната реалност и просторно и времено и симболички поставува нова.

Личните искуства за време на „Автономната зона“ се значајни за политичкиот процес во кој учествуваат студентите и во кој се поврзани со надминувањето на меланхоличната позиција на студентите. Анализата на податоците од истражувањето покажува дека телесните и дејствените афективни искуства ја одразуваат внатрешната и социјалната динамика, и овие искуства се носители на можностите за промена, односно трансформација на меланхоличното искуство. Специфичните 
услови и начинот на поврзување преку интерсубјективните и интерафективните искуства се засновани и овозможени преку хоризонталната организација и преку принципите на инклузивност, еднаквост во носењето одлуки и преземањето одговорност. Тие се главните услови за надминување на меланхоличната позиција на немоќ, потчинетост и изолација, кои ги зајакнаа студентите и влијаеа на нивната трансформација и социјална позиција.

Квалитетот на заедницата што студентите ја креираа врз основа на споделени вредности го овозможи остварувањето на споделените политички цели. Искуствата на студентите од „Автономната зона“ се земени како пример за креирање на нова политичка заедница што произлегува од социјално движење и е чекор напред во остварувањето на визијата за социјална промена што не се засновува на релации на моќ, түку на споделување на одговорност и грижа. Иако „Автономната зона“ има примарно политичка цел за зајакнување на притисокот кон институциите и одбрана на автономијата на Универзитетот, начинот на кој функционираше може да послужи како пример што ги поставува рамките на една мала политичка заедница заснована на политики на грижа.

\section{Литература}

Ahmed, Sara. The Cultural Politics of Emotion. Edinburgh: Edinburgh University Press, 2004.

Blazheva, Ana. „Emotions and the Political: The Transformative Potential of Melancholy“. Identities: Journal for Politics, Gender and Culture. Volume 13, 2016/17. Skopje: Institute of Social Sciences and Humanities - Skopje, 2017.

Cheng, Anne Anlin. The Melancholy of Race: Psychoanalysis, Assimilation and Hidden Greif. Oxford: Oxford University Press, 2000.

Durt, Christoph, Fuchs, Thomas, Tewes, Christian. Ed. Embodiment, Enaction, and Culture Investigating the Constitution of the Shared World. The MIT Press Cambridge, Massachusetts, London, 2017.

Eng, David L., Kazanjian, David. Loss: The Politics of Mourning. Berkeley: University of California Press, 2003.

Federici, Silvia. Caliban and the Witch: Woman, the Body and Primitive Accumulation. Brooklyn NY: Autonomedia, 2004.

Federici, Silvia. Revolution Point Zero: Household Reproduction and Feminist Struggle. Verlag: PM Press, Common Notions, 2012. 